\title{
George Enescu, Posthumously Reviewed
}

\author{
Valentina SANDU-DEDIU \\ National University of Music Bucharest \\ Strada Știrbei Vodă 33, București, Ro-010102 Romania \\ New Europe College Bucharest \\ Strada Plantelor 21, București, Ro-023971 Romania \\ E-mail: dediusandu@gmail.com
}

(Received: November 2017; accepted: January 2018)

\begin{abstract}
This essay tackles some aspects related to the attitude of the Romanian officials after George Enescu left his country definitively (in 1946). For example, recent research through the archives of the former secret police shows that Enescu was under the close supervision of Securitate during his last years in Paris. Enescu did not generate a compositional school during his lifetime, like for instance Arnold Schoenberg did. His contemporaries admired him, but each followed their own path and had to adapt differently to an inter-war, then to a post-war, Communist Romania. I will therefore sketch the approach of younger composers in relation to Enescu (after 1955): some of them attempted to complete unfinished manuscripts; others were influenced by ideas of Enescu's music. The posthumous reception of Enescu means also an intense debate in the Romanian milieu about his "national" and "universal" output.
\end{abstract}

Keywords: Securitate, socialist realism in Romania, "national" and "universal," heterophony, performance practice

It is a well-known fact that George Enescu did not create a school of composition during his lifetime, neither in the sense of direct professor-student transmission of information, as was the case in Vienna with Arnold Schoenberg, nor in the wider sense of a community of ideas or aesthetic principles. His contemporaries admired him, but they each had their own, well-established stylistic paths; in the Stalinist post-war period, some of them subordinated their work to the ideological requirements of socialist realism and it was generally discouraged to discern the subtle, but substantial renewals of Enescu's musical language. 
The official attitude towards Enescu, after he left Romania definitively in 1946, followed a precisely targeted propaganda: initially Enescu remained honorific president of the Society of Romanian Composers (which in 1949 became the Union of Composers of the People's Republic of Romania). Periodicals covered his tours with patriotic pride and reproduced chronicles of his achievements. Maria Cantacuzino, Enescu's wife, donated villa Luminiş, located in Sinaia, to the Ministry of Arts (in fact, she was forced to do so by the law that did not allow one to own more than one home in Romania). Gradually, however, around 1949, authorities started an increasingly strong attack against his "superficial" contact with the masses, given that only a few of his works were credited with an authentic folk spirit. That is to say that, after his promising beginning with the Romanian Rhapsodies (no. 1 in A major op. 11, 1901, no. 2 in D major op. 11, 1901), the composer "broke away from the life and wonderful source of inspiration that is the people and allows himself to be contaminated by the musical rottenness of the West". 1 The composer was not excluded officially, but simply omitted from the lists of members of the Union, together with other musicians who had settled abroad. This meant that, for a short period of time, he was absent from Romanian musical life. However, in 1951, when the Romanian Music Week festival was founded, George Enescu was invited to assume the role of president of honor. He sent back an elegant letter of refusal, which invoked the state of his health. Only as late as 1954 did his name reappear on the lists of Union members.

Recent research in the former Securitate archives has revealed the fact that, in the last years of his life, Enescu was under surveillance by Communist secret services, and even some of his close friends were reporting on every move made by the musician who had settled in Paris. ${ }^{2}$ History did not always do justice to Enescu, and professional and successful authors such as Lucian Boia have made sweeping statements regarding Enescu's attitude, accusing him of collaborating with the Communists in 1946 or blaming him for accepting to go on a concert tour in the U.S.S.R. ${ }^{3}$

1. Octavian Lazăr Cosma, Universul muzicii românești. Uniunea Compozitorilor și Muzicologilor din România, 1920-1995 [The universe of Romanian music. The Union of Composers and Musicologists in Romania, 1920-1995], (Bucharest: Editura Muzicală, 1995), 184.

2. See Ladislau Csendes, George Enescu: un exil supravegheat? [George Enescu: An exile under watch?], (Bucharest: Editura Casa Radio, 2011), and Ioana-Raluca Voicu-Arnăuțoiu, Muzicieni români, biografii ascunse în arhive [Romanian musicians, biographies hidden in archives], (Bucharest: Ars Docendi, 2011). Based on documents that have recently been discovered, these volumes show that the Securitate's reports also expanded to people who were close to the composer; also, Csendes emphasizes the fact that the Communist regime went out of its way to persuade Enescu to return to his country, so as to increase his credibility in the eyes of the Western world, which the musician always refused politely, but firmly.

3. The responses that tried to counteract such errors were not mediatized enough, but one must insist on their merit: Sever Voinescu, "Domnule Boia, depun recurs pentru George Enescu" [Mr. Boia, I am filing an appeal for George Enescu], in Dilema veche nr. 425 (5-11 aprilie 2012), also available under http://dilemaveche.ro/ sectiune/pe-ce-lume-traim/articol/domnule-boia-depun-recurs-pentru-george-enescu (last accessed on 10 October 2017), with reference to Lucian Boia, Capcanele istoriei. Elita intelectuală românească între 1930 şi 1950 [The traps of history. The Romanian intellectual elite between 1930 and 1950], (Bucharest: Humanitas, 2011). 
Beyond the biographical aspects, the particular situation of the reception of Enescu's music has also made the object of many comments. In Romania, Enescu's figure has always been admired and appreciated, posthumously became symbol of national music. Nevertheless, outside the Romanian borders, Enescu's composition did not have a very strong impact at the time: either the violinist's notoriety greatly surpassed the composer's, or the Romanian Rhapsodies' reception cast a shadow over subsequent works, whose complexity took longer to discover. After the war, the Communist regime in Romania speculated the best-known Romanian musician's name on the founding of the George Enescu International Festival and Contest in 1958. But the truly international glamour of the first editions faded away considerably in the 1980s, when Nicolae Ceaușescu succeeded in isolating Romania from the exterior almost completely. Fortunately, the Enescu Festival and Contest were revived after 1990 and their contribution to a more profound re-evaluation of Enescu's music and legacy cannot be questioned. At least the productions of Enescu's opera Oedipe (op. 23, 1931) on some of the greatest world stages (the latest at Covent Garden in 2016) draw attention to this important twentieth-century work that had been neglected for decades.

\section{Compositional reconstitutions}

The subtle interior mechanisms and the multiple facets of Enescu's creation have started to be thoroughly investigated by those composers whose debut took place towards the end of the 1950s and who constitute the most important generation of Romanian musicians active throughout the second half of the twentieth century. Most embarked on analyses of Enescu's scores, extracting ideas with the potential to instruct or inspire. The enormous bibliography on Enescu contains studies and volumes signed by composers such as Ştefan Niculescu, Pascal Bentoiu, Miriam Marbe, Adrian Raţiu, Cornel Ţăranu or Wilhelm Georg Berger, all of them examining the depths of Enescu's grammar and style. The attention drawn by Enescu's last opus, the Chamber Symphony (op. 33, 1954), whose modernity stands out in the contemporary Romanian repertoire, is further justified by numerous figures of the following generation who championed this idiom, as they sought to lay the foundations of a Romanian musical avant-garde in the 1960s. Enescu's music thus goes hand in hand with the interest in the Viennese School's dodecaphony, Pierre Boulez's and Karlheinz Stockhausen's serialism, in the music of Béla Bartók, Igor Stravinsky, Paul Hindemith or Olivier Messiaen. Such names, however, were not favored by contemporary socialist realism, which considered them decadent and mystical; it became ever more compelling to "cover" young modernists under Enescu's glory. Communist nationalism certainly favored the discovery of the folk vein in some of Enescu's work and any music claiming (more or less justifiably) to be drawing on Enescu was welcome. 
Stylistic continuations as such are, in fact, not that many. The most faithful connoisseur of Enescu's creation was Pascal Bentoiu, who started by dedicating the symphonic poem Luceafărul (The evening star) op. 7 to Enescu's memory. This symphonic poem, written in 1956-1957, immediately after Enescu's death, reveals valuable stylistic exercise instances, which bear Enescu's mark throughout Bentoiu's composition and musicological activity. I refer to his monograph on Enescu's works, released both in Romanian (1984) and English (2010), ${ }^{4}$ but also to the completion of the poem Isis (1923/1999), symphonies nos. 4 (1934/1996) and 5 (1941/1995) by Enescu, all of them left unfinished (therefore without opus numbers), to which we may add orchestrating the Sept Chansons de Clément Marot (op. 15, 1908/1998). ${ }^{5}$ Bentoiu carried out a minute research labor of a style in order to recreate it (in a way that is comparable to Friedrich Cerha's completion of Act III from Alban Berg's Lulu in the 1970s) and reached the innermost depths of Enescu's writing, managing to decode its meanings like nobody else. Inevitably, in many of his own compositions - the opera Hamlet (op. 18, 1969), instrumental concertos, the eight symphonies - one comes across echoes, suggestions, Enescian sonorities; nobody, however, could mistake Bentoiu for one of Enescu's epigones.

The delicate issue of reconstituting Enescu's drafts is currently a critical issue during a period when world-renowned performers and orchestras demonstrate increasing interest in Enescu's music. Some of these performers, mostly violinists, have always longed for that violin concerto that Enescu never wrote and have discovered drafts which the composer himself had not deemed worth pursuing. Thus, starting from a few music staves, works have been "completed" that do not represent Enescu at all, and which should not be promoted in the musical life, as they can only damage the reputation of this composer who was so well known for his high standards, his exquisite taste, and his refinement. However, due to the sincere enthusiasm of those who will not content themselves only with Enescu's masterpieces, we hear pieces of music that were only too often "finished" by others, which the drafts' author would never have approved of. Too little material was left from Enescu to base the Romanian Caprice (for violin and orchestra) on, as was the case with the orchestra miniature Voix de la nature. Examples may continue. This is why any reconstitution is practically impossible without betraying the essence of Enescu's style.

4. Pascal Bentoiu, Capodopere enesciene (Bucharest: Editura Muzicală, 1984); idem, Masterworks of George Enescu. A Detailed Analysis, translated by Lory Wallfisch (Lanham, Maryland: Scarecrow Press 2010).

5. There is another, earlier symphonic version, signed by Theodor Grigoriu (1964), as well as the reconstitution of another unknown score by Enescu: Caprice roumain for violin and orchestra by Cornel Țăranu (1925-1949/1997). 


\title{
2. "National" or "universal"?
}

If we thumb through post-war Romanian musicology specializing in Enescu's creation, it seems that one of the techniques that definitely marked other composers who followed Enescu would be a way to integrate folklore in forms belonging to the Western European tradition and to allude to "the Romanian folk character." This was achieved in the Sonata No. 3 for violin and piano (op. 25, 1926):

\begin{abstract}
...due to his immense genius, Enescu has shaped the entire Romanian sensitivity (musically speaking). In this sense, what belongs to Enescu but cannot be attributed to an explicit folkloric suggestion, remains a gain for the Romanian artistic and psychic characteristic generally. ${ }^{6}$
\end{abstract}

One must read between the lines of such a statement: it is precisely due to the subtlety of the way in which some suggestions were taken over from Romanian oral traditions, that this kind of Enescu-derived relationship with folklore is radically different from the neoclassical typology of the 1950s and 1960s, in agreement with socialist realism, which at the time aggressively promoted folk inspiration. On the other hand, some musicians - theorists and performers - have not avoided exaggeration in the description and rendering of a "national specific character" in the sonata no. 3 by Enescu, to the detriment of the European context in which it was written.

I have previously attempted to observe how sonata no. 3 was received almost 90 years after it was written, comparing multiple recordings, therefore focusing on the performance aspect. ${ }^{7} 1926$ was a significant year for an effervescent period in the history of Romanian music, a period of dynamic controversies over the national spirit and how it could be synchronized with European models. The twenty-first century inevitably brings a change of perception over sonata form. Is it still an appropriate time to stress the exoticism of this music (with its melodies loaded with enhanced seconds and microtonal pitches) in performance, as has been the case so far? If, at the time it was written, the Sonata was meant as a manifesto for the Romanian national school, at present the listener may look for a more pronounced European character of the music, of the Classical and Romantic construction. At any rate, the Romanian character is apparent without any doubt and cannot be avoided by any performer, given that it is indicated in the score in great detail through all the ornamentations and instrumental writing. Where are we, however, to look for the European character? In what tradition? If in Bartók's case one immediately feels Beethoven's lineage, what Western model can we find

6. Bentoiu, Masterworks of George Enescu, 519.

7. Valentina Sandu-Dediu, "Sonata a III-a pentru pian şi vioară de George Enescu. Interpretări comparate" [Sonata No. 3 for piano and violin by George Enescu. Comparing performances], in Secolul 21 2007/7-12, 348-353. 
for Enescu? I think that the reference can be a French impressionist one, in the sense of a sober detachment, but one not without finesse and expressiveness, on the part of the performer. This sonata is usually performed in a Romantic fiddler style, in my opinion just as unsuitable as a Brahms-like approach in performing the sonata for violin and piano by Claude Debussy.

After studying differing versions of the sonata no. 3 for piano and violin by Enescu (without claiming to have made the most appropriate selection, but nevertheless covering performers from different generations and geographies), I established a set of criteria to inform comparisons of respective performances, which were of course also determined by the texture and structural traits of the sonata. For example, an objective, detached approach to the score makes itself felt in a version recorded in England by Suzanne Stanzeleit and Julian Jacobson. ${ }^{8}$ The duo respects every single detail with admirable faithfulness, sobriety, and musical intuition. A Romanian listener might complain about the lack of a "fiddler feeling," or, on the contrary, might find the unprejudiced, obviously Western perspective on Enescu's music comforting. If I were to choose models for what the "Romanian folk character" means in this sonata, I would not think twice: the best choices would be the duos Enescu-Lipatti ${ }^{9}$ and Gheorghiu-Gheorghiu. ${ }^{10}$ But the English example has taught me that there also is a sustainable version for the "European character" of Enescu's music.

\section{Enescian techniques as a source of inspiration for Enescu's successors}

To return to Enescu's possible influences on post-war Romanian composition, I suggest reviewing a few concrete examples. A type of writing that has truly created a school, heterophony, theorized by Ştefan Niculescu, originates in archaic cultures and has been analyzed in Enescu's creation, where, "although dissimulated in a more or less traditional texture, it sets in as a specific mode of organization." ${ }^{11}$ The idea of combining the modal melos or the parlando-rubato rhythm with polyphony has further generated multiple varieties of writing, mainly

8. George Enescu: Music for Violin and Piano [Suzanne Stanzeleit - violin, Julian Jacobson - piano] CDE 84469 (London: Meridian Records, 2002).

9. Enescu și Lipatti interpretează Enescu și Lipatti / Georges Enesco and Dinu Lipatti Perform Their Own Compositions, 2CDs, EDC 430/431 (Bucharest: Electrecord, 2001), recorded in 1943.

10. Ştefan Gheorghiu - violin, Valentin Gheorghiu - piano, (Bucharest: Electrecord, [on LP: ST-ECE 01597] 1980, [on CD: 5948205012655] 2005), recorded in 1979.

11. Ştefan Niculescu, "Eterofonia" [Heterophony], in Studii de muzicologie [Studies in musicology] vol. 5 (Bucharest: Editura Muzicală, 1969), 63-77. One is bound to notice that the author's interest in heterophony is also stimulated by Pierre Boulez's considerations on "hétérophonie" in Penser la musique aujourd'hui (Paris: Gonthier, 1963), and that Clemansa Liliana Firca's study "Heterofonia în creaţia lui Enescu" / "L'hétérophonie dans la création musicale de Georges Enesco" was published around the same time in Studii de muzicologie, vol. 4 (Bucharest: Editura Muzicală, 1968), 307-314 (in Romanian), 315-319 (in French). 
inspired by the oblique dimension of heterophony. One of the defining features of Romanian music after 1960 remains the use of heterophonic texture, even if this seems to be related more to Witold Lutosławski's ideas than to Enescu's creation.

The construction principle of Enescian melody is interesting for the followers through the way in which it evokes folklore without actually citing it, through the microtonal pitches that give color to the tempered ones, through the ornaments and their transformation into thematic substance,,$^{12}$ through the use of characteristic motifs, cyclically related to and yet different from the leitmotif in the Western Romantic tradition.

In a direct relation to melody, harmony constitutes one of the features of an author's style, and in Enescu's case it is difficult to dissociate from heterophonic writing, where the horizontal dimension and the vertical one are already intertwined in a volatile way. Aspects of Enescu's harmonic language - such as the tonal-modal fusion, the insistence on the chromatic modi, the balanced dissonance-consonance relationship, the harmonic pedals on large surfaces - were also adopted by following generations. Moving beyond the serial phase, covered by some composers in the 1950s and 1960s, presupposed finding other new harmonic organizing modalities, and Enescu's model seemed to offer ideas once again. Tiberiu Oláh, for instance, declared:

My big discovery, as well as my colleagues', took place on the performance of Enescu's last works, in which his genius traced new composition conclusions from the general experience of the twentieth century and from that of heterophony - as the "primordial," "archetypal," and most universal aspect of multiphony. Enescu thus intuited a new "verticality" which I have called a procedure of "consonantizing dissonance" or of "emancipating consonance". We can talk about an absolutely intentional artistic response to Schoenberg's idea to emancipate dissonance, phrased by Enescu through a new method. ${ }^{13}$

There was also a lot of debate around the adaptation of the parlando-rubato rhythmic system (associated to improvisational style) to the Western metric system. The flow of Enescu's music, the complex stratification of heterophonic lines and fluid rhythms, has been compared to the folk genre of the Romanian doina, which is characterized by contemplative lyricism. ${ }^{14}$ An important part of post-war

12. Bentoiu, Masterworks of George Enescu, 513.

13. See the interview in the review of the Union of Composers and Musicologists from Romania by Monica Cengher, "Tiberiu Olah: 70," Muzica [new series] 9/1 (January 1998), 41.

14. See Ștefan Niculescu, "Aspecte ale folclorului în opera lui George Enescu” [Aspects of Romanian folklore in George Enescu's oeuvre], in Studii și Cercetări de Istoria Artei [Studies and researches in art history], 8/2 (Bucharest: Editura Academiei, 1961), 417-430. See also Bentoiu, Capodopere enesciene, 342. I refer here to the Romanian edition of Bentoiu's volume as the very paragraph I allude to is missing from the English translation of Lory Wallfisch. 
Romanian music inherits this contemplative feature, which it seems to prefer to the incisiveness of the giusto or aksak rhythms (even though, in Béla Bartók's descent, these have not been neglected either).

From among the formal principles of articulation of the musical discourse, the variation procedure - massively present in Enescu's creation - was preferred by many Romanian composers, sometimes as a solution to avoid the Beethovenian developing principle that had been exhausted by the Classical tradition. Other Enescian suggestions can be found in the music composed by generations of composers who followed him. Some of them included actual citations in works dedicated to the musician's memory, such as Homage to Enescu by Theodor Grigoriu (1960) and Synchrony II. An Homage to Enescu and Bartók by Ştefan Niculescu (1981).

One may establish two typologies in the presentation above: on the one hand, some technical ideas are taken over from Enescu (heterophony), but they are used along different aesthetic coordinates, or, on the other hand, there is an obvious continuation of Enescu's style, especially the style of his last works (the case of Pascal Bentoiu). Both directions imply an in-depth meditation on the meanings of Enescu's music. One concept that is extremely important to post-war composers, hence being often invoked, is synthesis, a model offered by Enescu intuitively through synchronization with Western music and at the same time the preservation of a "Romanian specific character." If one treats Enescu by coincidentia oppositorum, one transforms him into:

[a] protagonist for young composers. Long before the "syncretic" style phase (around 1960) he practiced the fusion of different types of composition and synthesis and had in mind the existence of a "nonlinear" time. ... Stopping time and a meditative attitude, so frequently noticeable in avant-garde music, are characteristic of Enescu ... ${ }^{15}$

$* * *$

Finally, it is interesting to look at the assimilations of aspects of Enescian language, visible in many of his successors' scores, to establish continuities in a possible Romanian school of composition. But even more significant, given its present-day relevance, is the idea of synthesis: just as the sonata no. 3 for piano and violin, "dans le caractère populaire roumain," demonstrated possibilities of fusion of violin microtonal pitches with piano tempering, of the free rhythm with the metric one, of oral culture-based improvisation with scholarly European art

15. Siegfried Borris, "Stilul enescian - exemplu de integrare a elementelor naţionale şi universale în muzica contemporană" [Enescu's style - An example of integrating national and universal elements in contemporary music), in Simpozion Enescu 1981, ed. Michaela Roșu (Bucharest: Editura Muzicală, 1984), 230. 
construction, ${ }^{16}$ some post-war Romanian composers tried in similar ways to graft a certain Romanian tone onto Western avant-garde trends. If nowadays the label "Romanian specific character" sounds outdated and reminiscent of a nationalist outlook which no longer matches contemporary ideology, it certainly dominated musicology and composition discourses between 1960 and 1990. It was, of course, generated in the context of Communist nationalism, but it should also be understood in a more nuanced manner. It comes from the complex of a marginalized musical culture, for which it was as imperiously necessary to become synchronized with the Western mainstream as it was to maintain its own identity. The same phrasing can no longer be applied to Romanian compositions after 1990, yet it cannot be neglected or minimized when we think of the decades that immediately preceded that year. And the examples I have selected come from this period. No composer whose debut took place after 1990 has claimed to be in any way Enescu's follower.

16. Cf. Ştefan Niculescu, "George Enescu şi a III-a sa Sonată pentru pian şi vioară" [George Enescu and his Third Sonata for piano and violin), in Simpozion Enescu 1981, 142-145. 
